\title{
Strengthening religious character education through Qiroah extracurricular activities
}

\author{
U. Najah* \& R. Umar \\ Universitas Negeri Malang, Malang, Indonesia \\ D.N. Wijaya \\ University of Porto, Porto, Portugal
}

\begin{abstract}
This study aimed to describe the character education strengthening program through qiroah extracurricular activities to realize religious values and identify obstacles faced and efforts to overcome them. This was a descriptive qualitative research. Observation, interview, and review of documents were procedures carried out for this study. Miles and Huberman's model of data analysis was used to validate and triangulate data. The results showed that the qiroah extracurricular activity program enables strengthening the religious character education through training activities or practice reading the Koran, praying the dhuha, istighosah, reading yasin, chanting tahlil and making pilgrimage to the grave. There were several obstacles to implement these activities. A few students came late and some of them did not have enough skills to be involved in those activities. Even so, qiroah extracurricular activities must be followed by seventh-grade and eight-grade students. The obstacles to implementing the qiroah extracurricular activity program in strengthening religious character education could be resolved properly.
\end{abstract}

Keywords: $\quad$ strengthening character education, extracurricular, Qiroah, Koran

\section{INTRODUCTION}

Character education needs to be taught to students in accordance with Law Number 20 of 2003 on the National Education System. The law mandated that national education serves to develop the ability and forms the character and civilization of a nation of dignity in order to educate the life of the nation, aiming to develop the potential for learners to become human beings that believe, have faith, noble character, health, knowledge, creativity, independence, and become democratic citizens and have responsibility. Until the National Education System Law Number 20 of 2003 replaced it, the National Education Law of 1946, which took effect in 1947, did not emphasize character education.

Bad character traits occur occasionally and the most serious one is students involved in a fight against other students. The above social phenomenon needs to be overcome by strengthening character education, this is due to the fact that religious character is eroded by globalization. Globalization has materialized the life of students. They engage more with their mobile phones, social media, and interesting games, instead of practicing their religion such as reading Koran. Contrary to the materialization that can cause secularism, religious practices can lead students to know themselves, others and develop good characters.

Data from the Central Statistics Agency of Jombang in 2019 showed that most of Jombang's residents believe in Islam, the number reaches $97.35 \%$ of the population. Therefore, the city is

*Corresponding Author 
also known as the santri city. Santri are students who dedicated their time to learning the religious practice of Islam. Jombang Regency has the vision to jointly realize a characterful and competitive of the regency. The vision has been transformed into the following missions: (a) to realize clean and professional governance, (b) to realize a quality, religious, and cultured community, (c) improve the competitiveness of the regional economy based on the potential for local and industrial excellence. One of the missions related to this study is to achieve the religious Jombang community. This mission can be understood as the goal of this community is to improve the Jombang community's quality of best religious character.

Students in Madrasah (a model of Islamic School) have diverse characteristics and come from different family backgrounds. They also have different habits. This fact is in accordance with the findings of research by Riza (2019). This research found that in achieving this goal Madrasah transfers religious values of learning and habituation of religious behavior. Madrasah Tsanawiyah Miftahul Ulum in Jombang also has extracurricular activities such as scouting, al-banjari, computers, drum bands, and qiro'ah. The choice of these activities proved that Madrasah Tsanawiyah Miftahul Ulum (MTs Miftahul Ulum) is an Islamic religious foundation that highlighted the religious character as the main foundation for education. MTs Miftahul Ulum has compulsory extracurricular attended by students in seventh-grade and eighth-grade. Extracurricular it is qiroah, a unique activity in the implementation of extracurricular qiroah in addition to training activities or practice of reading the Koran and learning the rhythm of the art of reading the Koran there are activities dhuha prayer, reading istighosah, reading the yasin and chanting tahlil, and making pilgrimage. The compulsory extracurriculars are in order to strengthen the religious characters of the learners.

\section{METHODS}

This research was a descriptive qualitative study. The aim of this study was to produce descriptive data in the form of written or oral words collected from people and the observable behavior of the participants. Qualitative research was more intended to understand existing phenomena such as a journalism, then develop in the form of writing using various scientific methods. Data sources there were informants, events that were by observing events during qiroah, and documents stored in the school, such as program books activities and photos of qiroh extracurricular implementation. Data collection procedure could be derived from interviews with the informant, namely the principal, qiroah extracurricular coaches, and students who follow qiroah; observation of the qiroah extracurricular activities, and photos taken during the qiroah extracurricular. Data analysis techniques using Miles and Huberman's qualitative data analysis models. According to Miles and Huberman, as quoted in Sugiono (2016), qualitative data analysis could be done starting from data reduction, data presentation, data conclusion, and data verification.

\section{RESULTS AND DISCUSSION}

\subsection{Qiroah extracurricular activity program in strengthening religious character education}

There are four programs of qiroah extracurricular activities applied in MTs Miftahul Ulum in addition to the main program of practice reading the Koran and learning the rhythm of the art of reading the Koran. Those programs are praying dhuha, reading istigosah, reading yasin, chanting tahlil and the grave pilgrimage. According to Awaliyah et al. (2018), character development is one of them with the habit of reading and worshiping in the congregation. Strengthened by the results of research by Hambali and Yulianti (2018) religious extracurricular programs include congregational prayer, the art of reading the Koran, takhfidzul Koran. This activity, madrasah, has a purpose, whch is to strengthen the religious character in students because religious values are very important for the provision of students when they have graduated madrasah and still bring a good attitude 
in accordance with the guidance of the Holy Koran as taught in Islam, as has been applied in the qiroah extracurricular program to strengthen the education of students' religious character. In accordance with Megawangi (2004), character education is an effort to educate children to make wise decisions and practice them in their daily lives, so that they can make a positive contribution to their environment.

\subsection{Implementation of qiroah extracurricular activities in strengthening religious character education}

Strengthening religious character education through qiroah extracurricular activities in the implementation of religious values manifested in qiroah extracurricular activities is very important. The extracurricular activities include exemplary values, disciplined values of worship, Islamic brotherhood values, and the value of sincerity. The implementation of those values aims to strengthen religious character education, so religious values need to be applied in its implementation. These values need to be maintained during the strengthening religious education so that students are accustomed to it and can practice it in everyday life and turn it into habit in its implementation. This research is in accordance with the findings of previous research entitled "Strengthening Religious-Based Character Education" by Suryanti and Widayanti (2018). The study mentioned that the religious-based character education strengthening program can improve the quality of schools starting by carrying out habituation activities in its implementation. religious located in Laskar Pembela Islam Malang City through the Maqoman Mahampang program and the everyday with Koran program.

\subsection{Constraints faced in implementing qiroah extracurricular activities in strengthening religious character education}

The obstacles faced in implementing qiroah extracurricular activities in strengthening religious character education are found in students and schools. Among them there are some students in reading the Koran with the rhythm of art or called qiroah. Some students do not have the same skills as other students, so some students become less interested, bored, and distracted, therefore, to strengthen religious characters such as those in implementation, namely excellence, discipline in worship, Islamic brotherhood and sincerity are not maximal because they make the atmosphere less conducive and in order. There are limited places in school so that the qiroah practice is divided into two sessions. In accordance with Kesuma (2013), strengthening and developing the values of life that are considered important and necessary so that it becomes a personality that is unique to students, as the values developed certainly have obstacles in their implementation, both from students and schools.

\subsection{Efforts to overcome obstacles in the implementation of qiroah extracurricular activities in strengthening religious character education}

In accordance with the obstacles faced in implementing qiroah extracurricular activities at MTs Miftahul Ulum, madrasah efforts to overcome obstacles to implementing qiroah extracurricular activities in strengthening religious character education are to motivate students to be interested in qiroah extracurricular activities in strengthening religious character education by exemplifying exemplary. By giving tausiyah to students through extracurricular activities, students can familiarize themselves with their daily lives. The solution so that students are interested and not bored and busy themselves is to add more than one qiroah teacher so that the atmosphere is not crowded and becomes conducive. This research is in accordance with previous research entitled "Strengthening Religious-Based Character Education" by Suryanti and Widayanti (2018) that some efforts can be made to realize these activities are exemplifying exemplary, creating a conducive environment.

The efforts of madrasas in overcoming space limitations by building larger madrasah prayer rooms so that they can be used for qiroah training are in accordance with the findings of research by 
(Budiyanto, 2018) layers of values and beliefs, as well as layers of assumptions, are manifested in the physical aspect of providing worship facilities and facilities support it, while in the behavioral aspect it is carried out with school programs. This is done to strengthen character education in students so that existing obstacles can be resolved with attitude and skills that must be developed so that students can possess the values of noble character which have become a good culture in madrasah. This research is in accordance with previous research entitled "Strengthening Character Education through Extracurricular Activities in Schools" by Dahliyana (2017). This study has similarities to the study by Dahliyana that shows extracurricular activities with character education, namely as an embodiment of knowledge gained in class with attitudes and skills that must be developed so that students can have in the form of noble character values that have become a culture in the social life of the school.

\section{CONCLUSIONS}

Based on the results of the research and discussion that has been presented in the previous results and discussions about the Strengthening of Religious Character Education through the Qiroah extracurricular. It can be concluded that there are four programs of qiroah extracurricular activities in strengthening religious character education at MTs Miftahul Ulum, including training programs or reading practicing the Quran and learning the rhythm of the art of reading the Koran, praying dhuha, reading istighosah, reading yasin, chanting tahlil, and making pilgrimage to the grave. The qiroah extracurricular program aims to strengthen the religious character education applied to students through extracurricular qiroah that can be applied to everyday life, which has interrelated programs, what is taught in the Koran reading program with artistic rhythms will be applied to other programs.

The implementation of qiroah extracurricular activities in strengthening religious character education at MTs Miftahul Ulum Ulum covers: (a) practice or practice reading the Koran and learning the rhythm of the art of reading the Koran, including recognizing recitation, knowing punctuation signs, understanding the meaning of verse readings, the length of the reading and learning the rhythm of the art of reading the Koran, (b) dhuha prayers are carried out on Saturdays and Mondays at the madrasa yard using mats in the morning before class starts, (c) reading istigosah, yasin, and tahlil are held in the morning the day before the learning hour starts every Thursday and at the beginning of each month in front of the class, (d) a grave pilgrimage is carried out in Jombang Regency, namely to the graves of the madrasah founders and the founding figures of Nahdlatul Ulama. This religious values that are manifested in the implementation of strengthening religious education in extracurricular activities including excellence, discipline in worship, Islamic brotherhood, and sincerity.

\section{REFERENCES}

Awaliyah, S. et al. 2018. The implementation of Regulation of the Minister of Education and Culture Number 23 Year 2015 Concerning Character Development in the Middle School. Advances in Social Science, Education and Humanities Research 251: 367-370.

Badan Pusat Statistik Kabupaten Jombang. 2019. Penduduk menurut agama yang dianut. Retrieved from https://jombangkab.bps.go.id/statictable/2020/08/19/5971/penduduk-menurut-agama-yang-dianut2019.html

Budiyanto, R. 2018. Pendidikan karakter religius berbasis budaya sekolah di SDIT Luqman Al-Hakim Internasional Yogyakarta. Jurnal Pendidikan Guru Sekolah Dasar 6(7): 581-592.

Dahliyana, A. 2017. Penguatan pendidikan karakter melalui kegiatan ekstrakurikuler di sekolah. Jurnal Sosioreligi 15(1): 54-64.

Gunawan, H. 2012. Pendidikan karakter. Bandung: Alfabeta.

Hambali, M. \& Yulianti, E. 2018. Ekstrakurikuler keagamaan terhadap pembentukan karakter religius peserta didik di Kota Majapahit. Jurnal Pedagogik 5(2): 93-208. 
Kesuma, D.D. 2013. Pendidikan karakter. Bandung: PT. Remaja Rosdakarya Offset.

Megawangi, R. 2004. Pendidikan karakter, solusi yang tepat untuk membangun bangsa. Bogor: Indonesia Heritage Foundation.

Riza, A. 2019. Peran madrasah diniyah dalam pembentukan karakter religius santri: Studi di Madrasah Diniyah Awaliyah Al-Muttaqin Rengging Kabupaten Jepara. (Unpublished Thesis). Semarang: Fakultas Ilmu Tarbiyah dan Keguruan Universitas Negeri Walisongo.

Sugiono. 2016. Metode penelitian pendidikan: pendekatan kuantitatif: kualitatif dan R\&D. Bandung: Alfabeta. Suryanti, E.W. \& Widayanti, F.D. 2018. Penguatan pendidikan karakter berbasis religius. In Sabar Setiawidayat et al. (eds.) Inovasi IPTEKS untuk mendukung pembangunan berkelanjutan; Proceeding Conference on Innovation and Application of Science and Technology, Malang, 12 September 2018. Malang: Universitas Widyagama Malang.

Republik Indonesia. 2003. Undang-Undang Nomor 20 Tahun 2003 Tentang Sistem Pendidikan Nasional. 